Ann. Biol. anim. Bioch. Biophys., 1978, 18 (2 B), 523-528.

\title{
Inhibition of nuclear maturation of isolated rat oocytes by follicular constituents
}

\author{
by A. TSAFRIRI
}

Department of Hormone Research, Weizmann Institute of Science Rehovot, P. O. Box 26, Israel.

\begin{abstract}
Summary. In vitro studies of mammalian oocytes led to the suggestion that a follicular factor, derived from granulosa cells (GC) and accumulated in follicular fluid (FFI), prevents the resumption of meiosis within the large Graafian follicle(s). The objectives of the present study were to test the effect upon the maturation of rat oocytes of (a) porcine FFI and a low molecular weight fraction thereof (PFFI), and (b) coculture with rat GC. Both FFI and PFFI inhibited the resumption of meiosis (germinal vesicle brakdown, GVB) of rat oocytes cultured with adherent cumulus cells. Coculture of oocytes with freshly isolated rat GC did not affect the spontaneous resumption of maturation, but GC cultured for $24 \mathrm{hrs}$ before adding the oocytes inhibited maturation. Culture of oocytes in a medium in which GC had been cultured for 48 hrs resulted in similar inhibition of meiosis. Addition of LH $(5 \mu \mathrm{g} / \mathrm{ml})$ overcame the inhibitory action of coculture with GC but only partially reversed the effect of GC conditioned medium and of PFFI. These studies demonatrate that (1) the maturation inhibiting action of porcine FFI is not confined to oocytes of that species ; (2) rat granulosa cells in culture produce a similar inhibitor of maturation; and (3) $\mathrm{LH}$ at least partially counteracts these inhibitory activities. These findings add support to the suggested role of GC in the control of oocyte maturation.
\end{abstract}

\section{Introduction.}

The in vivo dependence of the resumption of meiosis upon the preovulatory surge of gonadotropins is now well established. Administration of pentobarbitone sodium (Freeman, Butcher and Fugo, 1970 ; Ayalon ef al., 1972) or antiserum to the $\beta$-subunit of LH (Tsafriri et al., 1976a), or hypophysectomy (Vermeiden and Zeilmaker, 1974) of rats prior to the preovulatory gonadotropin surge prevented not only ovulation but also oocyte maturation. On the other hand, Pincus and Enzmann (1935) demonstrated that isolated rabbit oocytes mature spontaneously when cultured. This observation has been confirmed and extended to other mammalian species (reviewed by Biggers, 1972 ; Schuetz, 1974). The contrasting behaviour of oocytes within their follicles in vivo and of isolated oocytes in vitro led Pincus and Enzmann (1935) to suggest that either within the follicle the egg is maintained « in a nutritional state wherein nuclear maturation is impossible » or that follicle cells « supply a substance or substances which directly inhibit nuclear maturation $\gg$. Foote and Thibault (1969) presented evidence that oocyte contact with granulosa cells prevents the resumption of meiosis by porcine 
oocytes in culture. Our recent studies went further and demonstrated an inhibitory action of porcine granulosa cells (GC), GC extract and follicular fluid (FFI) upon the maturation of isolated porcine oocytes (Tsafriri and Channing, 1975 ; Tsafriri, Pomerantz and Channing, 1976b). These studies provided experimental support for a role of a follicular factor in the control of oocyte maturation.

In order to examine this hypothesis further, the ability of porcine FFI and a low molecular weight fraction thereof (PFFI) and of rat GC to inhibit the maturation of rat oocytes cultured together with their adherent cumulus cells was studied.

\section{Effect of porcine follicular fluid.}

Oocytes isolated 20 or $44 \mathrm{~h}$ after PMSG (15 i.u./rat) administration to 26 day old rats were cultured within their cumuli for 6 or $20 \mathrm{~h}$ in a medium containing either 50 p. $100(\mathrm{~V} / \mathrm{V})$ of porcine FFI or a low molecular weight fraction thereof (PFFI).

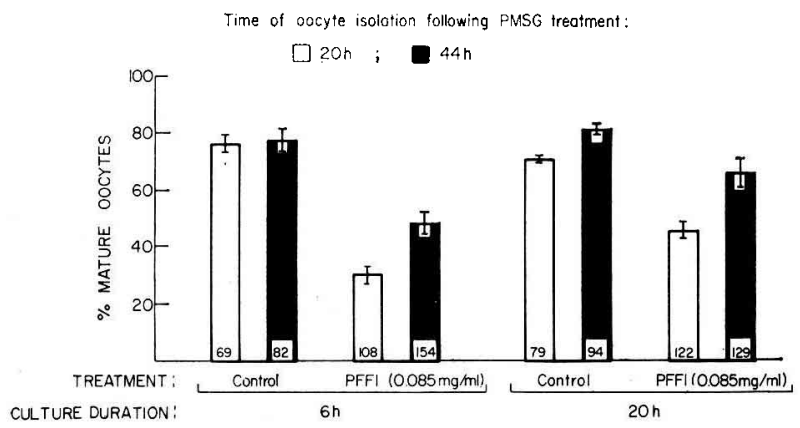

FIG. 1. - Effect of the low molecular weight fraction of porcine follicular fluid (PFFI) upon the maturation of rat oocytes in culture. Oocytes were isolated at the indicated time after PMSG (15 i.u./rat) administration to 26 day-old rats. The oocytes were cultured for 6 or $20 \mathrm{~h}$ in the presence or absence of $0.085 \mathrm{mg}$ protein $/ \mathrm{ml} \mathrm{PFFI}$. The number of oocytes examined are indicated on the columns ; vertical brackets, \pm SEM (From Tsafriri, Channing, Pomerantz and Lindner, 1977, by permiss ion).

Both FFI and PFFI (fig. 1) inhibited significantly germinal vesicle brea kdown (GVB) of isolated rat oocytes during a $6 \mathrm{~h}$ culture period. When incubation was extended to $20 \mathrm{~h}$ a number of oocytes reached GVB even in the presence of FFI or PFFI. The proportion of oocytes resuming meiosis was dependent on the dose of the inhibitor employed and on the developmental stage of the follicles from which the oocytes were derived. Oocytes isolated from preovulatory follicles, i.e. $44 \mathrm{~h}$ after PMSG-administration, were less sensitive to the inhibitor than oocytes harves ted from follicles $20 \mathrm{~h}$ following PMSG-treatment. It seems, therefore, that in add ition to the well established changes in follicular sensitivity and responsiveness to go nadotropins during follicular development, there is a concomitant reduction in the sensitivity of oocyles to the inhibitor of maturation. Due to this reduction in sens itiv ity only oocytes from animals $20 \mathrm{~h}$ after PMSG treatment were used in the rema ining experiments.

During the first $10 \mathrm{~h}$ of culture the percentage of GVB of ooc ytes cultured in the presence of $\mathrm{PFFI}(0.085$ and $0.170 \mathrm{mg}$ protein $/ \mathrm{m} \mathrm{l})$ remained approximately the 
same, and was dependent upon the dose of the inhibitor employed (fig. 2). During a second $10 \mathrm{~h}$ culture period further oocytes resumed maturation. Addition of $\mathrm{LH}$ $(5 \mu \mathrm{g} / \mathrm{ml})$ to the culture medium partially overcame the inhibitory action of PFFI (fig. 2). However, even in the presence of LH, PFFI caused a delay in GVB, which was directly related to the dose of the inhibitor used.

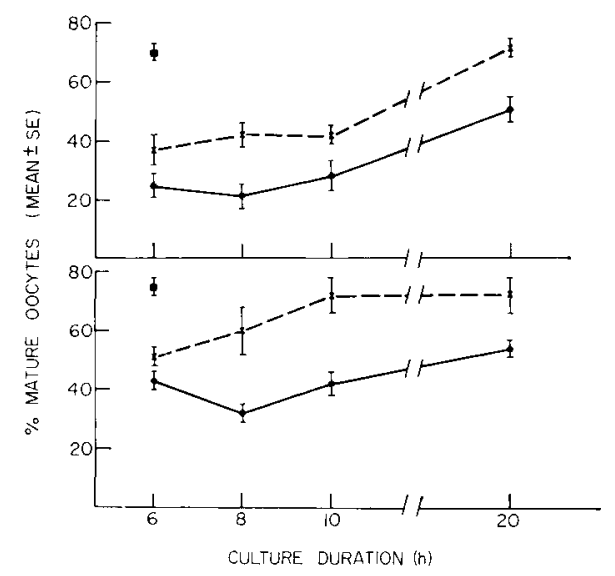

FIG. 2. - Effects of duration of culture and of $L H$ on oocyte maturation. Oocytes isolated from rats $20 \mathrm{~h}$ after PMSG treatment were cultured with PFFI (solid line; $0.085 \mathrm{mg}$ protein $/ \mathrm{ml}$-lower panel or $0.170 \mathrm{mg} / \mathrm{ml}$-upper panel) or with PFFI and LH $(5 \mu \mathrm{g} / \mathrm{ml}$; broken line). Vertical brackets, \pm SEM ; oocytes cultured without the inhibitor or LH (From Tsafriri, Channing, Pomerantz and Lindner, 1977, by permission).

\section{Effect of rat granulosa cells.}

Co-culture of freshly isolated granulosa cells and oocytes $20 \mathrm{~h}$ after PMSG administration to immature rats did not affect GVB during a $6 \mathrm{~h}$ culture period. However, when oocytes were added to GC cultured for $24 \mathrm{~h}$ previously, a dose-dependent inhibition of GVB was observed (fig. 3). This inhibition of maturation by GC was completely removed $(\mathrm{P}<0.001)$ by the addition of $\mathrm{LH}(5 \mu \mathrm{g} / \mathrm{ml})$ to the culture medium.

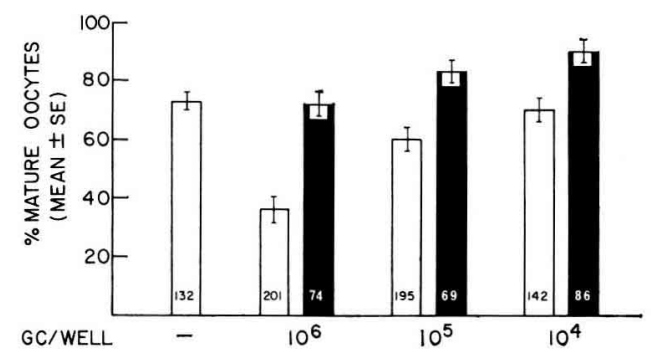

FIG. 3. - Effect of co-cuifure of rat granuiosa ceilis and oocyies upon the resumption of meiosis. Granulosa cells (GC) and oocytes were isolated $20 \mathrm{~h}$ after PMSG administration to immature rats. GC (number indicated) were cultured for $24 \mathrm{~h}$ in $0.2 \mathrm{ml}$ Eagle's medium on Falcon Microtest II plates. Freshly isolated oocytes (10-15) were then added to the culture alone (open columns) or together with $5 \mu \mathrm{g} / \mathrm{ml} \mathrm{LH}$ (black columns). Germinal vessicle breakdown was scored following a $6 \mathrm{~h}$ culture (mature oocytes). The number of oocytes cultured is shown on the columns; vertical brackets, \pm SEM. 
Similar inhibition of the resumption of meiosis was observed when oocytes were added to a GC conditioned medium, i.e. a medium in which GC were cultured previously for $48 \mathrm{~h}$ (fig. 4). In this case, LH only partially removed the inhibitory effect of the conditioned medium.

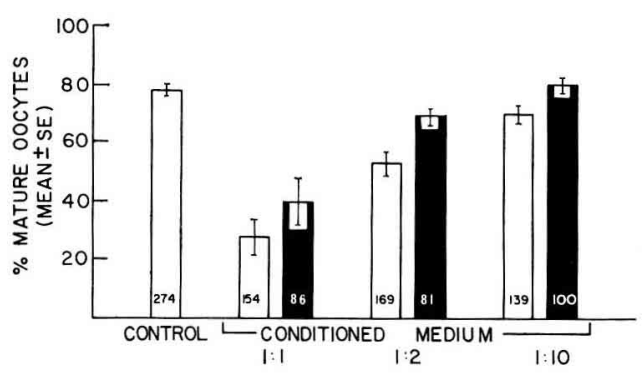

FIG. 4. - The effect of granulosa cell conditioned medium upon the maturation of rat oocytes. Granulosa cells $\left(10^{6} / \mathrm{ml}\right)$ were cultured for $48 \mathrm{~h}$ in Eagle's medium. The medium was then withdrawn and sterillized by filtration through millipore membrane $(0.22 \mu \mathrm{m})$. Oocytes were cultured for $6 \mathrm{~h}$ in the conditioned medium diluted with fresh medium as shown. Open colums, no hormone added ; black colomns, LH $(5 \mu \mathrm{g} / \mathrm{ml})$ added. The number of oocytes cultured is shown on the colums.

\section{Discussion.}

In the rat, resumption of the first maturation division can be achieved in vitro by (i) culturing oocytes liberated from their follicles or (ii) hormonal stimulation of explanted preovulatory follicles, e.g. with LH (Tsafriri ef al., 1972 ; Hillensjö, 1976). The timing of maturational changes differs in these two models, while GVB is completed within $2 \mathrm{~h}$ in the isolated oocytes, a $4 \mathrm{~h}$ culture period is needed for this change to occur in follicle-enclosed oocytes exposed to LH. Furthermore, puromycin, at dose levels which inhibit protein synthesis, does not prevent spontaneous GVB in denuded mouse oocytes (Stern, Rayyis and Kennedy, 1972 ; Golbus and Stein, 1976 ; Wassarman and Letourneau, 1976). However, puromycin does prevent LH-induced GVB in rat follicleenclosed oocytes (Tsafriri ef al., 1973). These results suggest that the isolated oocyte escapes the normal meiotic arrest, obviating the need for the regulatory steps involved in physiological hormone-induced maturation. The main objective of this study was to try to reconstitute gonadotropin dependence of maturation by the addition of follicular constituents to the isolated oocyle.

The results of this study demonstrated that (i) the inhibitor of maturation present in porcine follicular fluid is not species specific and that rat oocytes can be used as an assay system for further purification and characterization of this factor; (ii) the sensitivity of rat oocytes towards the inhibitor changes during follicular development ; (iii) rat granulosa cell cultures accumulate a similar inhibitor of oocyte maturation ; (iv) LH completely removes the inhibitory action of rat granulosa cells when added to co-cultures of oocytes and GC and partially when added to a medium containing PFFI or to GC conditioned medium.

Further study is required to define the mechanism by which follicular inhibitor exerts its action on meiosis and the mode of action of $\mathrm{LH}$ in overcoming this effect. 
LH may induce the resumption of meiosis by acting directly on the oocyte, through the mediation of follicle cells or by a direct interaction with FFI inhibitor. However, there is no conclusive evidence for a specific interaction of LH with the oocyte or with FFI. On the other hand, specific binding of LH by granulosa cells and their responsiveness to the hormone are well established (reviewed by Channing and Tsafriri, 1977). It seems reasonable, therefore, that the effect of $\mathrm{LH}$ on resumption of meiosis, too, is mediated by granulosa cells. This may explain the limited effect of $\mathrm{LH}$ in overcoming the inhibitory action of GC conditioned medium and the delay in GVB in the presence of PFFI and of LH. It is possible that the cumulus cells included in the culture were unable to act as substitutes for the granulosa cells of the whole follicle. This inability may be either due to the low number of cells included in the culture or due to the lesser ability of cumulus cells, compared to mural granulosa cells to bind LH (Amsterdam ef al., 1975).

The results of the present study add further support to the suggestion that a follicular factor, derived from granulosa cells and accumulated in follicular fluid prevents the resumption of meiosis within the preovulatory follicle. Nevertheless, these findings do not provide conclusive evidence for the physiological role of this factor in the control of maturation and do not define whether this factor is acting directly on the meiotic process or through the mediation of some other physiologically coupled process(es) involved in oocyte maturation. The complete removal of the inhibitory effect of granulosa cells co-cultured with oocytes by the addition of LH resembles closely the behaviour of rat follicle-enclosed oocytes. It is hoped that further studies with co-cultures of rat granulosa cells and oocytes will enable the definition of the primary site(s) and mechanism(s) involved in both, the inhibition of maturation by $\mathrm{GC}$ and in the induction of meiosis by luteinizing hormone.

$27^{e}$ Congrès international des Sciences physiologiques, Symposium « Germ and somatic cell interaction 》 Paris, 21-23 juillet 1977.

Acknowledgements. - This research was supported in part by the Ford Foundation, The United States-Israel Binational Science Foundation, BSF, Jerusalem, Israel and the WHO. The author thanks Drs. C. P. Channing and S. H. Pomerantz, University of Maryland School of Medicine for their kind collaboration and assistance, and Dr. H. R. Lindner for the interest taken in this study. The expert technical assistance of Mrs. A. Tsafriri and Mrs. M. Schattner is gratefully acknowledged.

Résumé. Les études in vitro des ovocytes de mammifères amènent à l'idée qu'un facteur folliculaire provenant des cellules de la granulosa (GC) et qui s'accumule dans le liquide folliculaire (FFI) empêche la reprise de la méïose dans les gros follicules de de Graaf. Nous avons testé l'effet, sur la maturation nucléaire de l'ovocyte de rat, (a) du liquide folliculaire de truie (FFI) ou d'une fraction de bas poids moléculaire (PFFI) et (b) de la coculture zvec des cellules de granulosa de rat. FFI et PFFI inhibent la reprise de la méïose (rupture de la vésicule germinative, GVB) d'ovocytes de rat entourés de leur cumulus. La coculture d'ovocytes et de cellules de granulosa fraîchement isolées n'empêche pas la reprise spontanée de la maturation, mais les cellules de granulosa cultivées $24 \mathrm{~h}$ avant l'addition des ovocytes inhibent la maturation. De même, dans un milieu dans lequel les GC ont été cultivées pendant $48 \mathrm{~h}$, les ovocytes ne reprennent pas leur méïose. L'addition de $\mathrm{LH}(5 \mu \mathrm{g} / \mathrm{ml})$ 
abolit l'action inhibitrice de la coculture avec les CG, mais n'a qu'un effet partiel sur l'effet du milieu de culture des GC ef du PFFI. Ces études démontrent que (1) l'action inhibitrice sur la maturation du liquide folliculaire de truie n'est pas limitée à cette espèce, (2) que les cellules de granulosa de rat en culture produisent également un inhibiteur de la maturation nucléaire ; (3) que la LH abolit au moins partiellement ces activités inhibitrices. Ces résultats apportent des éléments en faveur d'un rôle des cellules de la granulosa dans le contrôle de la maturation nucléaire de l'ovocyte.

\section{References}

AMSTERDAM A., KOCH Y., LIEBERMAN M. E., LINDNER H. R., 1975. Distribution of binding sites for human chorionic gonadotrophin in the periovulatory follicle of the rat. J. Cell Biol., 67, 894-900.

AYALON D., TSAFRIRI A., LINDNER H. R., CORDOVA T., HARELL A., 1972. Serum gonadotrophin levels in proestrous rats in relation to the resumption of meiosis by the oocytes. J. Reprod. Fert., 31, 51-58.

BIGGERS J. D., 1972. Metabolism of the oocyte, 241-252. In BIGGERS J. D., SCHUETZ A. W., Oogenesis, Univ. Park Press, Baltimore.

CHANNING C. P., TSAFRIRI A., 1977. Mechanism of action of luteinizing hormone and folliclestimulating hormone on the ovary in vitro. Metabolism, 26, 413-468.

FOOTE W. D., THIBAULT C., 1969. Recherches experimentales sur la maturation in vitro des ovocytes de truie ef de veau. Ann. Biol. anim. Bioch. Biophys., 9, 329-349.

FREEMAN M. E., BUTCHER R. L., FUGO N. W., 1970. Alteration of oocytes and follicles by delayed ovulation. Biol. Reprod., 2, 209-215.

GOLBUS M. S., STEIN M. P., 1976. Qualitative patterns of protein synthesis in the mouse oocyte. J. exp. Zool., 198, 337-342.

HILLENSJO T., 1976. Oocyte maturation and glycolysis in isolated pre-ovulatory follicles of PMSinjected immature rats. Acta endocr., 82, 809-830.

PINCUS G., ENZMANN E. V., 1935. The comparative behaviour of mammalian eggs in vivo and in vitro. J. exp. Med., 62, 665-675.

SCHUETZ A. W., 1974. Role of hormones in oocyte maturation. Biol. Reprod., 10, 150-178.

STERN S., RAYYIS A., KENNEDY J. F., 1972. Incorporation of amino acids during maturation in vitro by the mouse oocyte ; effect of puromycin on protein synthesis. Biol. Reprod., 7, 341-346.

TSAFRIRI A., LINDNER H. R., ZOR U., LAMPRECHT S. A., 1972. In vitro induction of meiofic division in follicle-enclosed rat oocytes by $\mathrm{LH}$, cyclic AMP and prostaglandin $\mathrm{E}_{2}$. J. Reprod. Fertil., 31, 39-50.

TSAFRIRI A., LIEBERMAN M. E., BARNEA A., BAUMINGER S., LINDNER H. R., 1973. Induction of ovum maturation and of steroidogenesis in the isolated Graafian follicle by luteinizing hormone : Role of RNA and protein synthesis. Endocrinology, 93, 1378-1386.

TSAFRIRI A., CHANNING C. P., 1975. An inhibitory influence of granulosa cells and follicular fluid upon porcine oocyte meiosis in vitro. Endocrinology, 96, 922-927.

TSAFRIRI A., LIBERMAN M. E., KOCH Y., BAUMINGER S., CHOBSIENG P., ZOR U., LINDNER H. R., 1976a. Capacity of immunologically purified FSH to stimulate cyclic AMP accumulation and steroidogenesis in Graafian-follicles and to induce ovum maturation and ovulation in the rat. Endocrinology, 98, 655-661.

TSAFRIRI A., POMERANTZ S. M., CHANNING C. P., 1976b. Inhibition of oocyle maturation by porcine follicular fluid : partial characterization of the inhibitor. Biol. Reprod., 14, 511-516.

TSAFRIRI A., CHANNING C. P., POMERANTZ S. H., LINDNER H. R., 1977. Inhibition of maturation of isolated rat oocytes by porcine follicular fluid. J. Endocr., 75, 285-291.

VERMEIDEN J. P. W., ZEILMAKER G. H., 1974. Relationship between maturation division, ovulation and luteinization in the female rat. Endocrinology, 95, 341-351.

WASSARMAN P. M., LETOURNEAU G. E., 1976. Meiotic maturation of mouse oocytes in vitro ; association of newly synthesized proteins with condensing chromosomes. J. Cell Sci., 20, 549-568. 